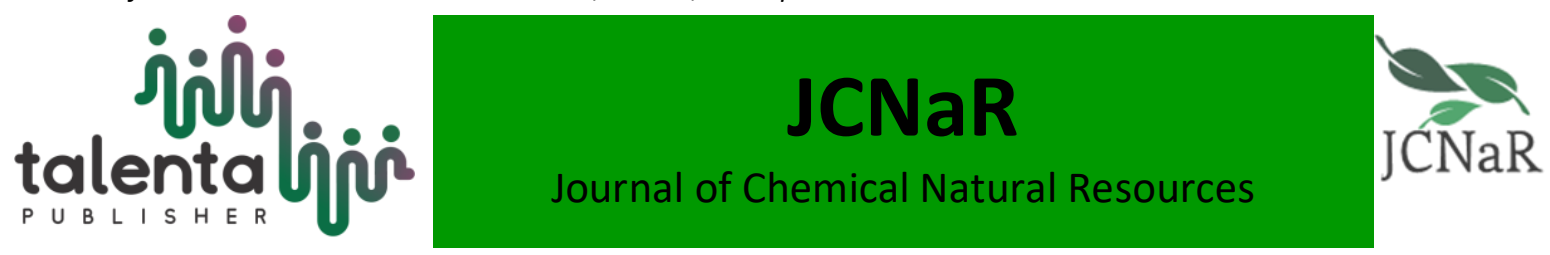

\title{
The Cytotoxic Activities of the Extracts of Sengkubak (Pycnarrhena cauliflora) As Apoptosis Inducers to Hela Cervical Cancer Cells
}

\author{
Masriani $^{1 *}$, Mustofa $^{2}$, Sunarti $^{3}$, Jumina $^{4}$ \\ ${ }^{1}$ Department of Chemistry Education, Faculty of Teacher Training and Education, University of \\ Tanjungpura, Pontianak, 78124, Indonesia \\ ${ }^{2}$ Department Pharmacology, Faculty of Medicine, University of Gadjah Mada, Yogyakarta, 55281, \\ Indonesia \\ ${ }^{3}$ Department of Biochemistry, Faculty of Medicine, University of Gadjah Mada, Yogyakarta, 55281, \\ Indonesia \\ ${ }^{4}$ Department of Chemistry, Faculty of Mathematics and Natural Sciences, University of Gadjah Mada, \\ Yogyakarta, 55281, Indonesia
}

\begin{abstract}
Cancer has been considered as problematic medical issues both in developed and developing countries. Pycnarrhena cauliflora or Sengkubak (Pycnarrhena cauliflora) has a potential value as alternatives for anticancer medication. This study aims to evaluate the cytotoxic activities of Sengkubak (Pycnarrhena cauliflora), and investigate the induction for apoptosis mechanisms from the extracts $n$-hexane, dichloromethane, and methanol from roots, branches the leaves to HeLa cancer cells. The cytotoxic activities were analyzed by performing MTT methods, while induction analysis of apoptosis was conducted by utilizing the Acridine Orange/Ethidium Bromide (AO/EB) as visual nuclear methodologies. The extracts of roots dichloromethane showed the highest cytotoxic activities accounted for IC50 $70 \mu \mathrm{g} / \mathrm{mL}$ and these extracts were able to induce the apoptosis mechanisms. This study concludes that the Sengkubak (Pycnarrhena cauliflora) has the ability as a potential alternative for anticancer medications.
\end{abstract}

Keyword: Sengkubak (Pycnarrhena cauliflora), HeLa, Cytotoxic, Apoptosis

Received 30 July 2019 | Revised 26 August 2019| Accepted 29 August 2019

\section{Introduction}

Cancer has been major health issue both in developed and developing nations. Despite of its big number of cases and mortality with high chemo resistance and poor prognosis, cancer has been considered as new economics issue among society. The American Cancer Society has estimated that $1,529,000$ cases which led to 569,490 death cases occurred in 2010 (Jemal, 2010). The number of new cases has been reported accounted for 50,210 patients (Jemal, 2009). These

\footnotetext{
*Corresponding author at: Department of Chemistry Education, Faculty of Teacher Training and Education, University of Tanjungpura, Pontianak, Indonesia

E-mail address: masrianinugraha@yahoo.com
} 
numbers are projected to spent from 115.8 billion dollars in 2000 to 147.6 billion dollars of productivity costs in 2020 (Bradley, 2008). According to the IARC (2010), cervical cancer was the third highest rates of women cases in the world with 529 thousands of new cases in 2008.

The main method in cancer treatment in particular for cancer which has been in metastasis state is chemotherapy. Several factors have been considered as the obstacles in treating cancers with this method including high toxicity and resistance, and the low selectivity (Mesquite et al., 2009). Therefore, effective and efficient methods must be obtained in order to develop new anticancer medications. And one of the most promising methods is to develop new potential source which can be utilized as anticancer (Kim and Park, 2002).

Sengkubak which has Latin name of Pycnarrhena caulifora within the Menispermaceae family is one of the liana plants found commonly in the West Borneo. The leaves have been widely used as seasonings and flavorings for Dayak and Malay societies (Utin Trisna Afrianti, 2009). Another similar genus, such as P. ozanta has been reported to be containing bisbenzylisoquinoline which has antitumor activities (Loder, 1972; Abauchacraet et al., 1987). On the other hand, the ethanol extracts of Sengkubak (Pycnarrhena cauliflora) leaves have showed the antioxidant effects to IC50 $0.634 \mathrm{mg} / \mathrm{mL}$ (Masriani, 2011). Provided that the chemotaxonomy approach has the ability to prevent carcinogenesis mechanisms, Sengkubak (Pycnarrhena cauliflora) could have been considered as new potential alternatives for anticancer medications.

One of the challenges that have been encountered in cancer treatment is the ability of cancer cells in evading the apoptosis mechanisms. Several studies have reported that some cancer medications from plants provided cytotoxic effects to cancer cells through apoptosis induction (Kaufmann and Eainshaw, 2000). This research is conducted to investigate the cytotoxic effects and the induction of apoptosis mechanisms from roots, branches, and leaves of Sengkubak (Pycnarrhena cauliflora) to HeLa cervical cancer cells. Other related studies have never been reported to do, so that the results of this study are expected to be a reference in discovering and developing new anticancer substances from Sengkubak (Pycnarrhena cauliflora).

\section{Materials and Methods}

\subsection{Materials}

In this research, maceration glasses tools, rotary evaporator (Heidolph, Germany), treated tissue culture dish with $10 \mathrm{~cm}$ of diameter, 96 well-plate, 24 well-plate, cover slip (Thermanox ${ }^{\mathrm{R}}$ Plastic Coverslips), centrifuge tubes, object glasses, $\mathrm{CO}_{2}$ incubator, centrifugation (Sorvall ${ }^{\mathrm{R}}$ Legend RT), laminar air flow cabinet, micropipettes, autoclave, hemocytometer, inverted microscope (Axiovert 25), ELISA reader (Biorad), fluorescence microscope (Zeiss MC 80), digital camera (Nikon Coolpix L4, 4.0 megapixels), and optical microscope (Nikon YS100) were used. 
The materials were supplied from Gibco consisted by n-hexane, dichloromethane, methanol, $10 \%(\mathrm{v} / \mathrm{v})$ of Fetal Bovine Serum (FBS), $1 \%(\mathrm{v} / \mathrm{v})$ of penicillin-streptomycin, $0.05 \%(\mathrm{v} / \mathrm{v})$ of trypsin dissolved on Phosphate Buffered Saline (PBS), MTT (3-4,5-dimetiltiazol-2-il)-,5difeniltetrazoliumbromida, stopper of Sodium dodecyl sulfate (SDS), alcohol 70\%, while the amounts of Acridine Orange/Ethidium Bromide (AO/EB) were purchased from Sigma-Aldrich.

\subsection{The extractions of substances from Sengkubak (Pycnarrhena cauliflora)}

The numbers of roots, brunches, and leaves from Pycnarrhena cauliflora (Menispermaceae) were obtained from Bukit Dedai, Sintang, and West Borneo in June 2011, and the identification of the plants was conducted at Herbarium Bogoriense. As many as $500 \mathrm{~g}$ of roots, $600 \mathrm{~g}$ of branches, and $600 \mathrm{~g}$ of leaves were immersed differently with following solutions, which are $\mathrm{n}$ hexane, dichloromethane, and methanol. The immersion of every samples produced different percentage of samples which is displayed by table 1. After being extracted, each samples were tested the cytotoxic effects to the HeLa cervical cancer cells by utilizing the MTT as the methods, while the control samples of toxicity was doxorubicin.

\subsection{The test of cytotoxic effects by MTT methods}

The tests of cytotoxic effects of each extracts of n-hexane, dichloromethane, and methanol from roots, branches and leaves were conducted by MTT method for three times of testing. The HeLa cervical cancer cells were supplied by the laboratory of parasitology of medical faculty of University of Gadjah Mada. As many as $100 \mu \mathrm{L}$ cells were prepared with 5 different concentration of solutions, while the doxorubicin and DMS were used as positive and negative control samples respectively. The tests process were begun by incubating the cells for 24 hours after being washed with PBS for two times. Afterward, the amounts of cervical cells were added with $100 \mu \mathrm{L}$ MTT with ratio $5 \mathrm{mg} / \mathrm{mL}$ stock, and these samples were incubated for 4 hours within $37^{\circ} \mathrm{C}$ in $5 \%$ of carbon dioxide condition. The amounts of living cells produced reactions to form purple color of formazan. The reactions were stopped by adding $100 \mu \mathrm{L}$ of $10 \%$ sodium dodecyl sulfate (SDS) in $0.1 \mathrm{~N}$ hydrochloric acid conditions which was incubated for 12 hours within room temperature. After being incubated, the samples were measured by Benchmark microplate reader at $595 \mathrm{~nm}$ of wavenumber to investigate the absorbance properties. To determine the amounts of cells, mathematical calculations were conducted by the Equations 1. Finally, the cytotoxicity of samples extracts were determined by analyzing the linear regression of $\mathrm{IC}_{50}$ based on logarithmic concentrations compared to the percentage of inhibitory zones of the extracts to HeLa cervical cancer cells.

\subsection{The apoptosis test}

To measure the apoptosis mechanisms, the samples were placed onto isolation plate by coverslips. Every plate was added by $200 \mu \mathrm{L}$ of cell suspensions with $5 \times 10^{4}$ concentrations for 30 minutes which was incubated for 24 hours with $300 \mu \mathrm{L}$ of media agar in carbon dioxide conditions. After 24 hours, all of the media were removed, so that the coverslips were able to be 
moved by using the tweezers to object glasses. As many as $10 \mu \mathrm{L}$ of Acridine Orange/Ethidium Bromide (AO/EB) were prepared to be dropped gradually, and the samples were allowed to stand for certain times. Afterward, the samples were observed by using fluorescence microscope to investigate the living and death cells indicated by the green and orange colors respectively.

\section{Results and Discussion}

This study examines the cytotoxic activities of the extracts of Sengkubak (Pycnarrhena cauliflora) and doxorubicin by performing the (3-4, 5-dimetiltiazol-2-il)-, 5difeniltetrazoliumbromida (MTT) to HeLa cervical cancer cells. In this method, the cytotoxic activities were observed by the color changing of formazan from yellow to purple due to the reduction caused by the succinate dehydrogenase enzyme within living mitochondrial cells. This reduction was occurred as long as the numbers of both mitochondrial reductase enzymes that have been activated, and living cells are directly proportional (Lee, 2004). The percentage of living cells is calculated according to the following Equations 1.

$$
\% \text { living cells }=\frac{\text { cells absorbance to absorbancetests media }}{\text { control absorbance to cells absorbance media }} \times 100 \%
$$

The tests results showed that the percentage of living cells which is indicated by the purple color was influenced by the concentration levels of the extracts. The following Table 1 and Figure 1 illustrates the results of the tests for every samples used



A

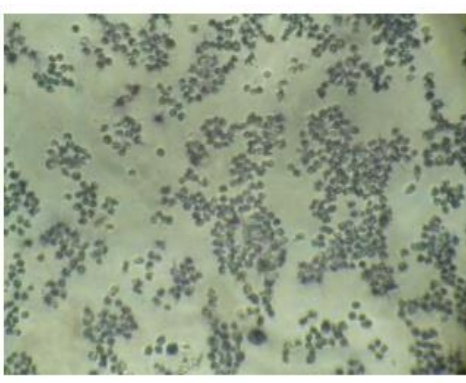

B

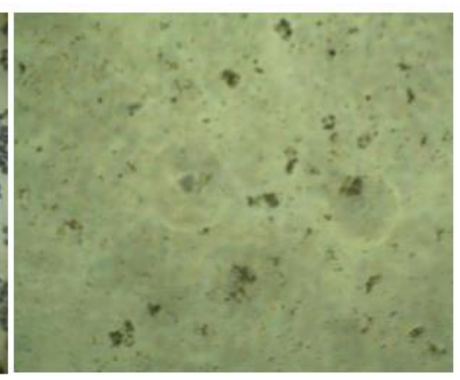

$\mathrm{C}$

Figure 1. The effects of the extracts samples in the formation of formazan to HeLa cervical cancer cells with different concentrations of the roots extracts (A) control, (B) the extracts of dichloromethane of roots $32.5 \mu \mathrm{g} / \mathrm{mL}$, and $(\mathrm{C})$ the extracts of dichloromethane of the roots for $500 \mu \mathrm{g} / \mathrm{mL}$ 
Table 1. The results test of $\mathrm{IC}_{50}$ for the extracts of samples based on the plants parts

\begin{tabular}{lll}
\hline Plant parts & Extracts & $\mathrm{IC}_{50}(\mu \mathrm{g} / \mathrm{mL})$ \\
\hline \multirow{2}{*}{ Roots } & n-hexane & 141,7 \\
& dichloromethane & 70,0 \\
& methanol & 99,1 \\
& n-hexane & 130,8 \\
Branches & dichloromethane & 90,7 \\
& methanol & 393,4 \\
& n-hexane & $>500$ \\
Leaves & dichloromethane & $>500$ \\
& methanol & 368,8
\end{tabular}

The values of $\mathrm{IC}_{50}$ from extracts samples from different parts of the plants showed that the highest activities of cytotoxic were in doxorubicin as the control variable for $1.08 \mu \mathrm{g} / \mathrm{mL}$. The extracts of n-hexane and dichloromethane were the lowest value accounted for less than $>500$ $\mu \mathrm{g} / \mathrm{mL}$, suggesting the lowest level of cytotoxic effects. Compared to the others extracts, the dichloromethane extracts from the roots plants provided the highest value of $\mathrm{IC}_{50}$ accounted for $70.0 \mu \mathrm{g} / \mathrm{mL}$. Based on the value of $\mathrm{IC}_{50}$, only the methanol extracts of roots, dichloromethane extracts of the roots, and dichloromethane extracts of the branches have the $\mathrm{IC}_{50}$ values under $100 \mu \mathrm{g} / \mathrm{mL}$. Nevertheless, it these values are compared to the cytotoxic effects of doxorubicin, the values were far beyond the control variables. These differences were occurred due to the rough extracts of the samples, while the doxorubicin control variable used was fine substances.

In rough extractions, substances have many impurities which could have provided antagonist properties due to the presence of active constituents. Subsequently, the cytotoxic effects of this extracts provide are lower activities than those doxorubicin have, so that the process of purifying the extracts has important role in preventing the growth cancer cells. The cytotoxic levels of Sengkubak (Pycnarrhena cauliflora) is sequenced as $\mathrm{HA}>\mathrm{MA}>\mathrm{DB}>\mathrm{HB}>\mathrm{HA}>\mathrm{MD}>\mathrm{MB}=\mathrm{HD}$, which is based on the Figure 2 of logarithmic graphs below. 


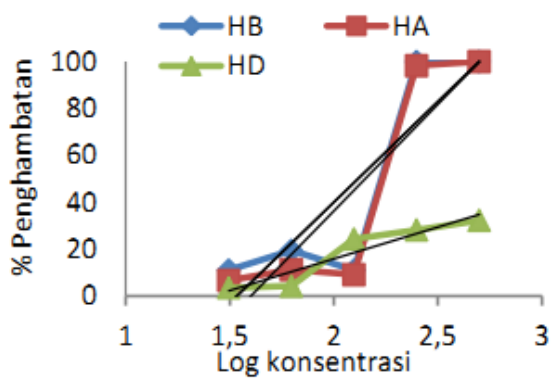

(A)

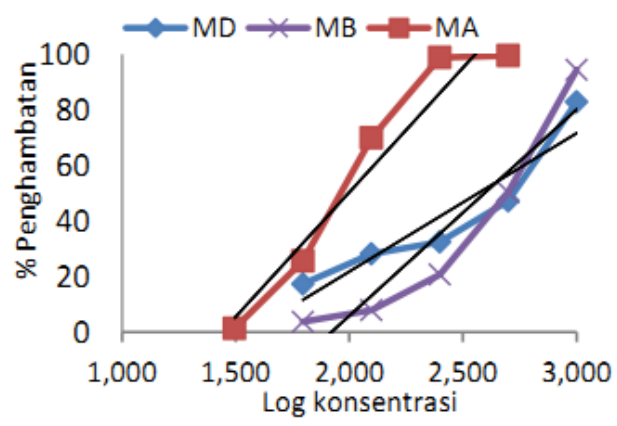

(C)

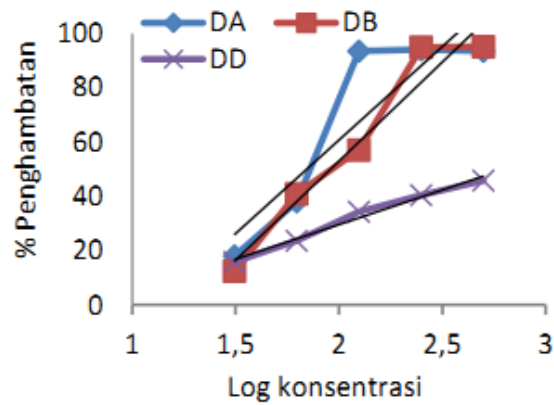

(B)

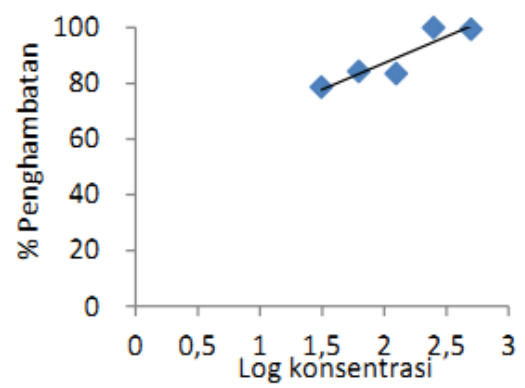

(D)

Figure 2. The effects of extracts Sengkubak (Pycnarrhena cauliflora) to the growth of HeLa cervical cancer cells based on the parts of the plant (A) n-hexane of roots (HA), branches (HB), and leaves (HD); (B) dichloromethane of roots (DA), branches (DB), and leaves (DD); (C) methanol of roots (MA), branches (MB), and leaves (MD); (D) Doxorubicin

The cytotoxic tests results showed that the extracts of Sengkubak (Pycnarrhena cauliflora) had different de-accelerating effects to the growth of HeLa cervical cancer cells based on the Figure 2. These differences occurred due to the cytotoxic substances contained within the extracts, while another assumption was based on different of degrees or grades although the presence of cytotoxic among every sample could be found (Lieberman et. al., 2001). Chatelain et al., (2008) also have reported that the substances ability in preventing the growth of cancer cells is one of the effects. Figure 2 previously demonstrates that the increasing of inhibitory effects of Sengkubak (Pycnarrhena cauliflora) extracts to HeLa cervical cancer cells are influenced by the increasing concentrations, which indicates the presence of high levels of toxin within the extracts (Lieberman et. al., 2001). Moreover, these results suggest that the inhibitory effects of extracts Sengkubak (Pycnarrhena cauliflora) have the potential abilities as in vivo anticancer medications (Trimurtulu et. al., 1994).

The apoptosis mechanisms or biological programmable death of cells are the biological physiological mechanism in removing the unwanted cells (Hu and Kavanagh, 2003). This process is begun by inducing the cells which is important for anticancer medications (Frankfurt and Krishan, 2003). In order to investigate the effect of cytotoxic of the Sengkubak (Pycnarrhena cauliflora) extracts to the apoptosis induction, an observation based on the colors indicator of the (3-4, 5-dimetiltiazol-2-il)-, 5-difeniltetrazoliumbromida (MTT) was conducted. The following Figure 3 represents the observation of induction to the HeLa cervical cancer cells. 


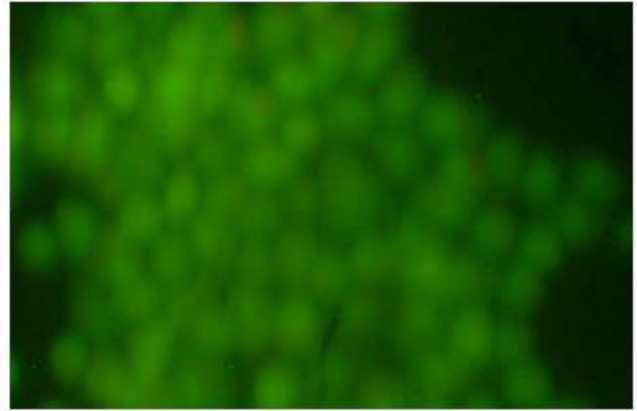

(A)

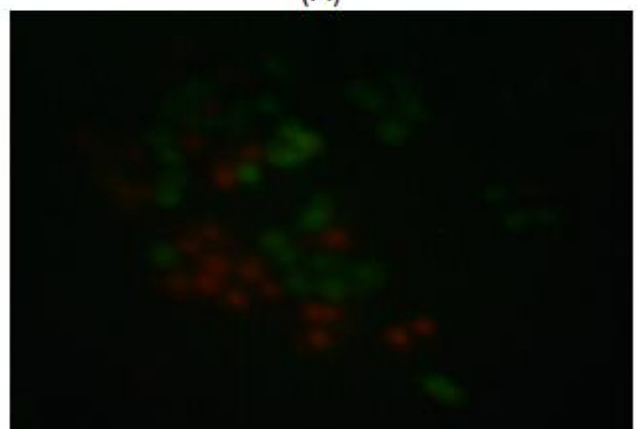

(C)



(B)

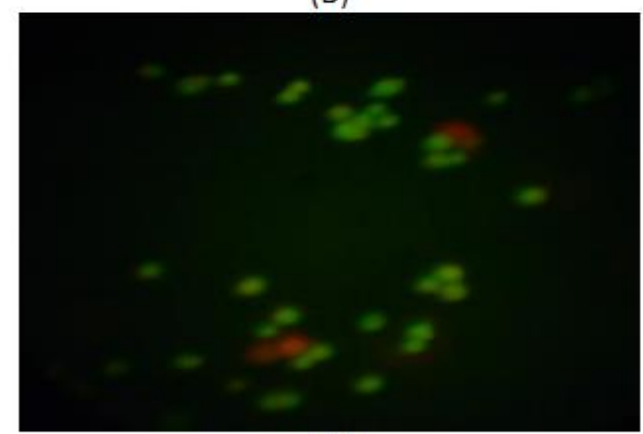

(D)

Figure 3. Photographic images of the effects of Sengkubak (Pycnarrhena cauliflora) extracts to the apoptosis induction mechanisms to the HeLa cervical cancer cells (A) control sample, (B) methanol extracts of roots, (C) dichloromethane extracts of branches, and (D) dichloromethane extracts of roots.

The Figure 3 illustrates the apoptosis mechanisms for different samples compared to the control samples. According to the images, the green colors indicated the living cells, while the orange colors suggested that the apoptosis mechanisms occurred in the final stages. The orange colors of every images indicated that the HeLa cervical cancer cells have experience the DNA fragmentation stages. The addition of edithium bromide caused the intercalation process between the edithium bromide and the DNA which had experienced the DNA fragmentation (Spector, 1998). These results showed that the cytotoxic effects of the extracts of Sengkubak (Pycnarrhena cauliflora) were occurred compared to the control variable.

Although in this study, the identification of constituents which have induced the apoptosis mechanisms as well as the cytotoxic effects was not conducted, the phytochemical analysis suggested that the chemical substances, which have played role in the mechanisms, are alkaloids, steroids, and terpenoids. The following Table 2 displayed the phytochemical analysis of the extracts samples based on the parts of the plants.

Table 2. Preliminary phytochemical analysis of the extracts samples of Sengkubak (Pycnarrhena cauliflora)

\begin{tabular}{lllllll}
\hline Plant & \multirow{2}{*}{ Extracts } & \multicolumn{5}{l}{ Phytochemical Constituents } \\
\cline { 3 - 7 } parts & n-hexane & + & + & + & - & - \\
\hline \multirow{3}{*}{ Roots } & dichloromethane & + & + & + & - & - \\
& methanol & - & - & + & - & +
\end{tabular}




\begin{tabular}{lllllll}
\multirow{2}{*}{ Branches } & n-hexane & + & + & + & - & - \\
& dichloromethane & + & + & + & + & - \\
& methanol & - & - & - & - & - \\
\multirow{2}{*}{ Leaves } & n-hexane & + & + & + & - & - \\
& dichloromethane & + & + & + & + & - \\
& methanol & - & - & - & + & + \\
\hline
\end{tabular}

According to Ritcher et al., (2003), the apoptosis mechanisms within the cells induced by terpenoids are occurred because of the presence of inhibiting of topoisomerase enzymes. On the other hand, it has been reported that steroids substances induce the cells to perform apoptosis mechanisms throughout the Bax activation (Choi et al., 2003). The anticancer activities of alkaloid compounds could have been occurred by the abilities of these compounds in inhibiting the cycle cells throughout the induction of p53 and p $21^{\text {cipl }}$, which have been reported by Meng et al., (2004).

\section{Conclusions}

The extracts of dichloromethane of roots and branches, as well as the roots-methanol extracts have the cytotoxic activities to the HeLa cervical cancer cells. Based on the $\mathrm{IC}_{50}$ test results, the values are respectively $70.0 ; 90.74 ; 99.11 \mu \mathrm{g} / \mathrm{mL}$, and these extracts have the abilities to induce the apoptosis mechanisms. The phytochemical analysis suggests that the constituents such as steroids, terpenoids, and alkaloids are contained in Sengkubak (Pycnarrhena cauliflora) parts of roots, branches, and leaves, while the flavonoids are only found in the roots, and leaves. Interestingly, saponins constituents are obtained only from roots, and leaves of the plants. These findings conclude that the Sengkubak (Pycnarrhena cauliflora) plants are one of the plants that could be utilized as the anticancer medications due to the presence of anticancer activities.

\section{References}

[1] Abaouchacra, M.L., 1987. The bisbenzylisoquinoline alkaloid of Phycnarrhena ozantha. Nat. Prod., 50:375-80

[2] Akroum, S., Satta, D., and Lalaoui, K., 2009. Antimicrobial, antioxidant, cytotoxic activities and phytochemical screening of some Algerian plants. Eur. J. Sci. Res., 2;28995

[3] Bradley, C.J., Yabroff, K.R., Dahman, B., Feuer, B.J., Mariotto, A., and Brown, M.L., 2008, Productivity Costs of Cancer Mortality in the United States: 2000-2020, J.Natl. Cancer Inst., 100: 1763-70

[4] Chatelain, K., Phippen, S., McCabe, J., Teeters, C., O’Mallety, S., Kingsley, K., 2008. Cranberry and grape seed extract inhibit the proliferative phenotype of oral squomosa cell carcinoma. eCAM (Advance Acces published on July 23);

[5] Choi, Y.H., Kong, K.R., Kim, Y.A., 2003. Induction of Bax and activation of caspasesduring $\beta$-sitosterol mediated apoptosis in human colon cancer cells, Int. J. Oncol., 3:1657-62

[6] Fisher, D.E., 1994. Apoptosis in cancer therapy: crossing the threshold, Cell, 78:539-42 
[7] Jemal, A., Siegel, R., Ward, E., Hao, Y., Xu, J., andThun, M.L., 2009, Cancer Statistic 2009, CA Cancer J. Clin., 59;225-249

[8] Jemal, A., Siegel, R., Xu, J., Ward, E., 2010. Cancer statistics, 2010. CA Cancer J. Clin., 60:277-300

[9] Kasibhatla, S. and Tseng, B., 2003. Why target apoptosis in cancer treatment? Mol. Cancer Ther., 2:573-80

[10] Kaufman, S.H. andEarnshaw, W.C., 2000. Induction of apoptosis by cancer chemotherapy. Exp. Cell Res., 256: 42-9

[11] Kim, J., and Park, E.J., 2002. Cytotoxic anticancer candidates from natural products. Curr. Med. Chem, 2:485-537

[12] Lee, J.Y., Hwang, W.I., and Lim, S.T., 2004. Antioxidant and anticancer activities of organic extract from Platycodongrandiflorum A.de Condolle Roots, J. Ethnopharmacol., 93:409-13

[13] Liebermann, M.M., Patterson, G.M.L., and Moore, R.E., 2001. In vitro bioassay for anticancer drug screening: effects of cell concentration and other assay paraameterson growth inhibitory activity. Cancer Lett., 173;21-9

[14] Loder andNeam, 1972. Tumor inhibitory plants: Two newbisbenzyisoquinoline alkaloid from Pycnarrhena ozantha (Menispermaceae). Chemistry, 25(10):2193-7

[15] Lowe, S.W. dan Lin, A.W., 2000. Apoptosis in cancer. Carcinogenesis, 21 (3):485-95

[16] Masriani, Eny Enawaty, dan Adniana, I, K., 2011. Aktivitas antioksidan ekstrak etanol daun Sengkubak (Pycnarrhena cauliflora) (Pycnarrhena cauliflora (Miers) Diels) asal Kalimantan Barat. Prosiding Seminar Nasional Herbs for Cancer. Universitas Islam Sultan AgungTirtayasa Semarang 4 Juni 2011

[17] Meng, L,H., Zhang, H., Hayward, L., Takemura, H., Shao, R.G., andPommier, Y., 2004. Tetrandine induces early G1 arrest in Human colon carcinoma cells by down regulatingg the activity and inducing the degradation of G1-S-specific cyclin-dependent kinases and by inducing $\mathrm{p} 53$ and $\mathrm{p} 21^{\mathrm{Cip} 1}$. Cancer Res., 64:9086-96

[18] Mesquite de, M.C., Paula de, J.E., Pessoa, C., Moraes de, M.O., Costa-lotufo, L.V., Groughnet, R.M..S., Tillequin, L.S., 2009. Cytotoxic activity of Brazilian Cerradoplants used in traditional medicine againts cancer cell line. J. Ethnopharmacol., 123:439-45

[19] Ritcher, S.N., Menegazzol, I., Fabri, D., Palumbo, M., Concerted bis-alkilatyng reactivity of clerocidin towards unpaired cytosine residues in DNA. Nuclei Acids Res., 32:5658-67

[20] Spector,D. 1998. Cells, A laboratory manual, subcellular localization of genes and their product, volume 3, Cold Spring Harbor Laboratory Press, USA. 